Diabetologia 11, 313-320 (1975)

(C) by Springer-Verlag 1975

\title{
Insulin Secretion in the Perinatal Period of the Rat
}

\section{In Vivo and in Vitro Effects of Glucose and Glibenclamide (HB 419)}

\author{
E. Heinze, W. Beischer, J. Osorio, and E.F. Pfeiffer* \\ Dept. of Endocrinology and Metabolism, Center of Internal Medicine and Pediatrics, University of Ulm, Germany
}

Received: January 3, 1975, and in revised form: May 23, 1975

\begin{abstract}
Summary. During the perinatal period of the rat the effect of glucose and glibenclamide (HB 419) on the secretion of insulin was studied in vivo and in vitro. In the in vitro experiments isolated islets of 21 day old fetal and 5 day old newborn rats were perifused with $16.7 \mathrm{mM}$ glucose or $16.7 \mathrm{mM}$ glucose plus $1 \mu \mathrm{g} / \mathrm{ml}$ glibenclamide, while in the in vivo experiments glucose, $0.5 \mathrm{~g} / \mathrm{kg}$ of body weight, or glibenclamide, $0.5 \mathrm{mg} / \mathrm{kg}$ of body weight were tested. Glucose elicited a small first phase of insulin release in 21 day old fetal islets, while glucose plus glibenclamide evoked a biphasic pattern. The injection of glibenclamide to the mother lowered the blood sugar in
\end{abstract}

the fetus and increased the fetal serum insulin concentration. In one day old newborn rats glibenclamide stimulated the secretion of insulin after an i.p. injection. Glucose was without effect. Both substances increased the serum insulin concentration in five day old newborn animals. Dynamic studies at that age revealed a monophasic response to glucose and a biphasic pattern to glucose plus glibenclamide.

Key words: Insulin secretion, perinatal period, rat, in vivo, in vitro, perifusion, isolated islets, glucose, glibenclamide.
Attention has been directed to the similarities between the fetal pattern of insulin secretion and the prediabetic subject [1]. Evidence for this comparison is derived from the observations that glucose is a poor stimulus for insulin secretion in the perinatal period of different species including man [2-4]. Under certain conditions altered dynamics of insulin release in response to the same stimulus were reported for the prediabetic human subject [5-7]. For the rat it has been repeatedly shown that the effect of glucose on insulin secretion is weak in the fetus while there is a significant response in the newborn animal $[8-10]$.

Most of these results were obtained with static incubation procedures and conclusions drawn from these observations are limited. With the development of the perifusion technique a system became available which overcomes the difficulties for dynamic studies when only minute amounts of tissue are available like the fetal and newborn pancreas of the rat. In view of the proposed similarities between the fetal and the prediabetic pattern of insulin release the effects of glucose and glucose plus glibenclamide on the dynamics of insulin secretion were studied in isolated islets of 21 day old fetal and 5 day old newborn rats. In addition to these in vitro experiments both substances were tested in vivo.

\footnotetext{
* Supported by Deutsche Forschungsgemeinschaft, SFB 87.
}

\section{Material and Methods}

The methods employed for keeping the animals and isolation of the islets have been reported in detail elsewhere $[9,11]$. Briefly, Wistar albino rats $(200 \mathrm{~g})$ were mated for $36 \mathrm{hrs}$. The first day was designated as day one of fecundation. 21 days later the fetuses were obtained by caesarian section under light ether anesthesia while other pregnant rats were allowed to deliver vaginally. The fetuses or newborn were sacrificed by decapitation. For the in vitro experiments the islets of Langerhans were isolated by the collagenase method [12] (Serva Heidelberg, Germany). For each experiment 100 islets were collected and transferred to a Duralon millipore filter (diameter $13 \mathrm{~mm}$, pore size $14 \mu \mathrm{m}$ ) placed in a millipore holder (Millipore, Neu-Isenburg, Germany) which served as the perifusion chamber. With a peristaltic pump a Krebs-Ringer bicarbonate buffer, $\mathrm{pH} 7.4$, supplemented with $0.5 \mathrm{mg} / \mathrm{ml}$ of bovine serum albumin (Behringwerke, Marburg, Germany) was passed through the chamber with a flow rate of $0.7-0.75$ $\mathrm{ml} / \mathrm{min}$. The buffer was continuously gassed with a mixture of $95 \%$ oxygen and $5 \%$ carbon dioxide throughout the experiment. The perifusion chamber and the buffer reservoir were kept in a water bath at $37^{\circ} \mathrm{C}$. The effluent was collected in test tubes with a 
fraction collector. During the first $60 \mathrm{~min}$ the glucose concentration of the buffer was $2.2 \mathrm{mM}$. The effluent of the last $15 \mathrm{~min}$ of this period was collected in three separate fractions of $5 \mathrm{~min}$ representing the baseline for each preparation.

This prestimulation period was followed by the stimulation period which lasted for $35 \mathrm{~min}$. During this time $16.7 \mathrm{mM}$ of glucose with or without $1 \mu \mathrm{g} / \mathrm{ml}$ of glibenclamide (HB 419) (Boehringer, Mannheim, Germany) were tested, followed by a post-stimulation period of $25 \mathrm{~min}$ in which the islets were again perifused with $2.2 \mathrm{mM}$ glucose.

In the in vivo experiments 21 day old fetal and 1 and 5 day old newborn rats were used. In the study with the fetal rats normal saline or $0.5 \mathrm{mg} / \mathrm{kg}$ glibenclamide was injected into the jugular vein of the mother. Twenty minutes later the fetuses were obtained by caesarean section. The animals were killed by decapitation, and the blood was collected from the neck vessels. For the studies with the newborn rats the litters of three mothers were pooled. Thus, for one single experiment 25-32 newborn were used which were randomly distributed in three equal sized groups. The first group of animals was injected with normal saline i.p. while the second and third group received either glucose, $0.5 \mathrm{~g} / \mathrm{kg}$ of body wight, or glibenclamide in the same concentration as the fetal rats. The first group of animals was sacrificed $15 \mathrm{~min}$ after the injection, the second group $10 \mathrm{~min}$ and the third group $20 \mathrm{~min}$ after the injection of the test substances.

Serum glucose was measured in duplicate with a hexokinase method adapted for small volumes [13] while the immunoreactive insulin from the perifusion experiments and from the in vivo studies was determined according to Melani et al. [14]. Rat insulin was used as a standard (Dr. J. Schlichtkrull, Novo Research Institute, Copenhagen, Denmark).

For the statistical analysis Student's t-test was used.

\section{Results}

\section{In Vivo Studies}

When glibenclamide (HB 419) in a dose of 0.5 $\mathrm{mg} / \mathrm{kg}$ of body weight was injected into the jugular vein of the mother the blood glucose concentration in the fetus decreased from $38 \pm 4 \mathrm{mg} \%$ at zero minutes to $24 \pm 6 \mathrm{mg} \%$ at twenty minutes $(\mathrm{M} \pm \mathrm{SEM} ; \mathrm{n}=9$; $p<0.05$ ), while the insulin concentration in the serum was augmented from $95 \pm 7 \mu \mathrm{U} / \mathrm{ml}$ to $155 \pm 17(\mathrm{M} \pm \mathrm{SEM} ; \mathrm{n}=9 ; p<0.0025)$. In control experiments normal saline did not change the concentration of glucose or insulin.
Fig. 1 shows the effect of the sulfonylurea in the same amount injected intraperitoneally on the secretion of insulin in 1 and 5 day old newborn rats. In the younger age group the serum insulin concentration was increased from $65 \pm 6 \mu \mathrm{U} / \mathrm{ml}$ before the injection of the drug to $95 \pm 14 \mu \mathrm{U} / \mathrm{ml}$ at twenty minutes. From the basal concentration of insulin this is a stimulation close to $50 \%$. In 5 day old newborn animals insulin release was augmented by about $100 \%$ during the same time interval from $20 \pm 4 \mu \mathrm{U} / \mathrm{ml}$ to $43 \pm 6 \mu \mathrm{U} / \mathrm{ml}$. The concentration of insulin was higher in one than in five day old newborn rats, which was again shown in another series of experiments, where glucose at a dose of $0.5 \mathrm{~g} / \mathrm{kg}$ of body weight was injected to one and five day old newborn rats (Fig. 2). Glucose did not stimulate the secretion of insulin during the first $24 \mathrm{hrs}$ after delivery but it enhanced the serum insulin concentration in 5 day old newborn rats.

\section{Perifusion Studies}

Fig. 3 shows the effect of glucose on the dynamics of insulin release from isolated islets of 21 day old fetal rats. When the glucose concentration was changed from $2.2 \mathrm{mM}$ at the prestimulation period to $16.7 \mathrm{mM}$ at the stimulation period an immediate response of insulin secretion was observed. From this peak value insulin gradually declined during the following minutes to baseline concentrations. A second small but insignificant increase was observed at the end of the stimulation period. When the glucose concentration in the buffer was changed from $16.7 \mathrm{mM}$ to 2.2 $\mathrm{mM}$ during the last $25 \mathrm{~min}$ insulin slowly decreased to baseline. At that age glibenclamide remarkably enhanced the second phase of insulin secretion (Fig. 4).

A different dynamic pattern of insulin release was observed with isolated islets of 5 day old newborn rats (Fig. 5). At that age the basal concentration of insulin was between 50 and $60 \mu \mathrm{U} / \mathrm{ml}$, which was obtained when 100 isolated islets per chamber were perifused with $2.2 \mathrm{mM}$ of glucose. From this concentration insulin release was immediately stimulated when the glucose concentration was changed to $16.7 \mathrm{mM}$. The secretion of insulin did not decline during the following minutes, it remained high during the whole stimulation period of $35 \mathrm{~min}$. At that time the glucose concentration was changed to $2.2 \mathrm{mM}$ and insulin gradually declined, but remained elevated for another 25 min to the end of the perifusion until the basal concentration was reached. The effect of $16.7 \mathrm{mM}$ of glucose plus $1 \mu \mathrm{g} / \mathrm{ml}$ of glibenclamide (HB 419) on the dynamics of insulin release in 5 day old newborn rats is shown in Fig. 6. During the $60 \mathrm{~min}$ stimulation period 


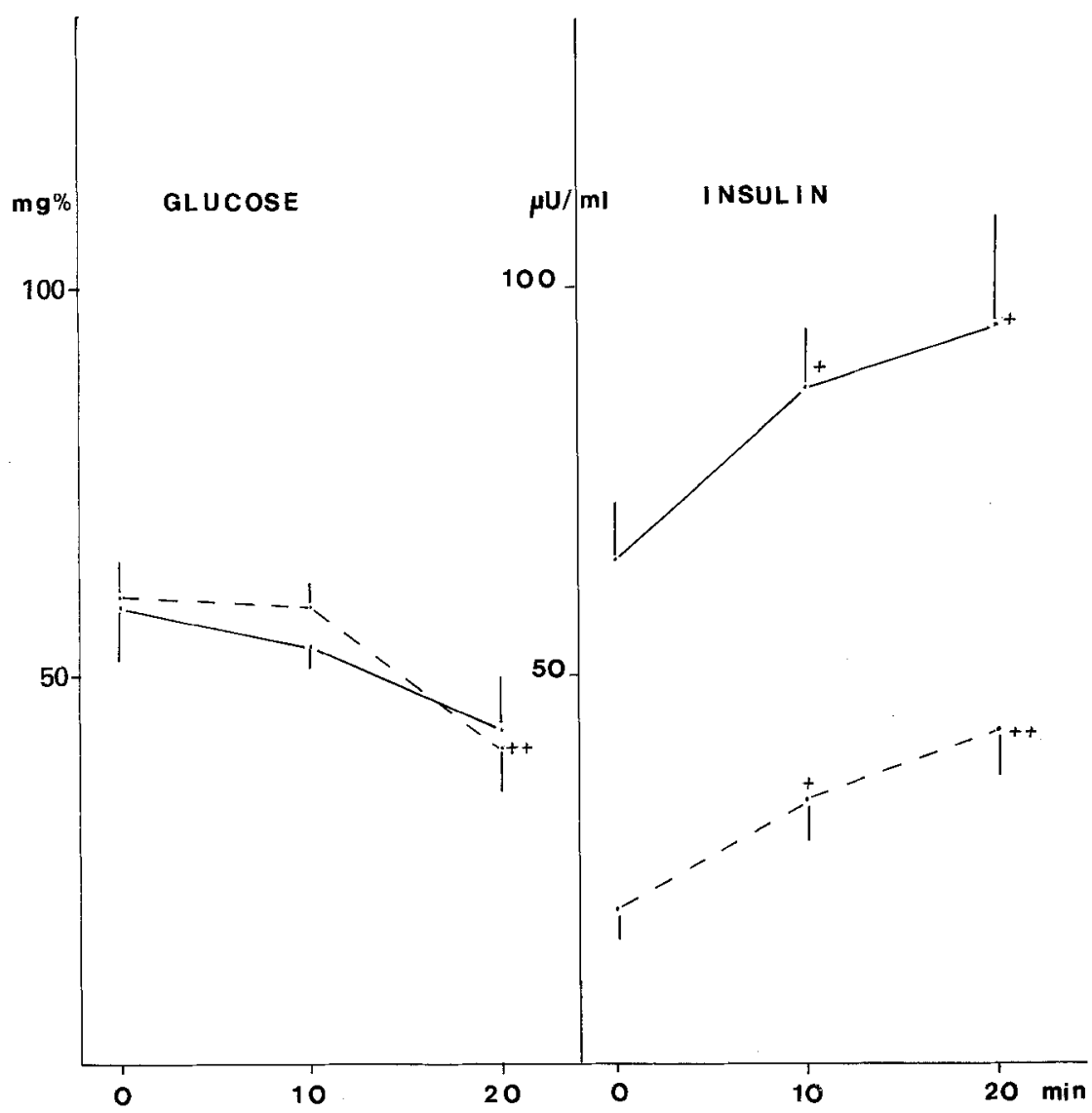

Fig. 1. The effect of glibenclamide (HB 419), $0.5 \mathrm{mg} / \mathrm{kg}$, i.p. on serum glucose and insulin in one day old ( $\longrightarrow$ ) and five day old $(--)$ newborn rats. Mean \pm SEM; $\mathrm{n}=6$ for one day; $\mathrm{n}=12$ for 5 day; ${ }^{+} p<0.05 ;^{++}<0.005 ;^{+++}<0.0005 ;$ significance of difference from zero minutes

with $2.2 \mathrm{mM}$ of glucose an insulin concentration of about $65 \mu \mathrm{U} / \mathrm{ml}$ was reached, which represents the baseline. From this level the combination of $16.7 \mathrm{mM}$ glucose and $1 \mu \mathrm{g} / \mathrm{ml}$ of glibenclamide stimulated the release of insulin within three minutes to $124 \mu \mathrm{U} / \mathrm{ml}$. After this peak concentration insulin declined towards baseline values at 8 to $9 \mathrm{~min}$. Then a second rise of insulin secretion was observed, which did not last for the whole stimulation period. During the final perifusion period using again a glucose concentration of 2.2 $\mathrm{mM}$, the insulin concentration in the effluent continued to decrease.

Table 1 summarizes the results of the perifusions. The duration of the phases was arbitrarily defined by comparison of the individual experiments.

\section{Discussion}

The results on insulin secretion in the perinatal period of the rat presented in this study, are derived from in vivo and in vitro experiments. They demonstrate certain limitations of each method and may help to clarify the pattern of insulin release during that period of life. The well known variation of insulin release from isolated islets is confirmed in this study. This has been attributed to the insulin content and the anatomical location of the islets within the pancreas [15]. Furthermore, the irregularity of response may be related to the summation of the individual experiments for statistical evaluation $[2,21]$. Nevertheless, perifusion of isolated islets from 21 day old fetal rats with glucose evoked a brief increase in insulin release from the B-cells. The results are in agreement with previous reports where glucose stimulated the first phase of insulin secretion in perifusion experiments from cultured explants [2] or from pieces of the fetal rat pancreas [17]. However, the second phase of insulin secretion was small or absent. This is in contrast to the adult pancreas [16]. Furthermore, during an i.v. glucose tolerance test the fetal rat pancreas did not secrete any measurable insulin though the K-value was normal, [18]. This result 


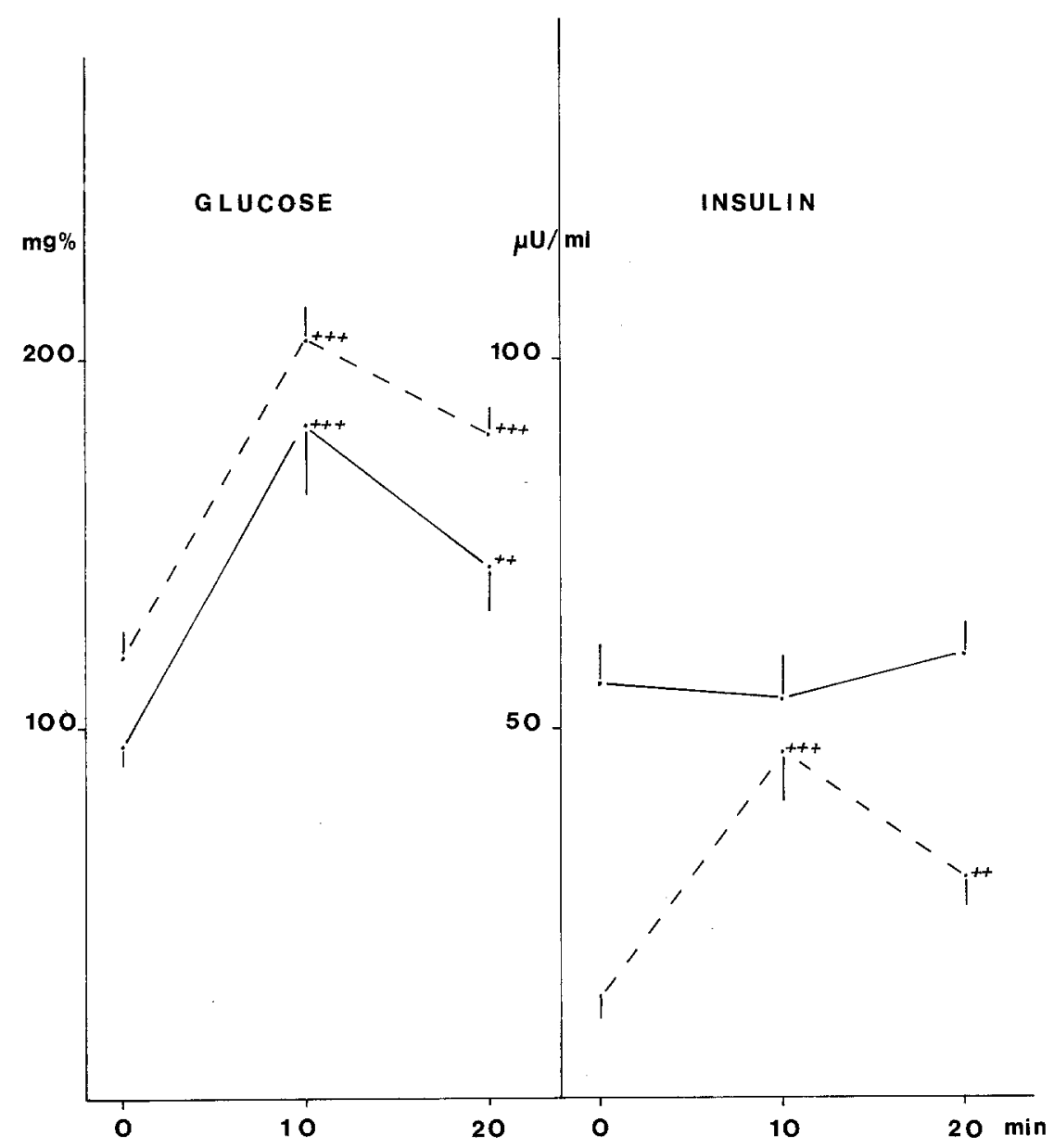

Fig. 2. The effect of glucose, $0.5 \mathrm{~g} / \mathrm{kg}$, i.p. on serum glucose and and insulin in one day old (-) and five day old (---) newborn rats. Mean $\pm \mathrm{SEM} ; \mathrm{n}=9 ;{ }^{+} p<0.05 ;{ }^{++}<0.005 ;{ }^{+++}<0.0005 ;$ significance of difference from zero minutes

may be related to the very small insulin release from the fetal B-cells in response to glucose. At that age glibenclamide influenced both phases of insulin secretion, which was further supported by the results of the in vivo experiments. Glibenclamide lowered the fetal blood sugar and stimulated the secretion of insulin, when the drug was injected into the maternal jugular vein.

Tolbutamide, another sulfonylurea compound, failed to increase the insulin output from the fetal endocrine rat pancreas, this differs from our results and may be explained, at least in part, by the dose of tolbutamide used in these static incubations or the fetal B-cells are more sensitive to glibenclamide [10, 18].

In the in vivo experiments during the first $24 \mathrm{~h}$ after delivery glucose did not increase the secretion of insulin despite marked hyperglycemia, while glibenclamide significantly stimulated the release of the hormone in the newborn rats. The dose of glucose and glibenclamide used in these experiments was comparable since both agents provoked a nearly similar amount of insulin release in five day old newborn rats. The failure of glucose to enhance the secretion of insulin in one day old newborn rats underlines the results obtained with the fetal islets. that the amount of the hormone released is small and that conclusions about insulin secretion during that period of life depend largely on the sensitivity of the methods which are used $[8,9,19,20]$. The dynamics of insulin release from isolated islets of five day old newborn rats gave a different pattern for glucose and glibenclamide. No biphasic secretion was observed with glucose while glibenclamide elicited a first and second phase of insulin release. The failure of glucose to provoke a biphasic insulin secretion in these islets is similar to other studies where the first phase of insulin release was only detected in individual experiments $[21,22]$.

One reason for this failure may be seen in the isolation procedure with collagenase [23]. However, glibenclamide elicited this biphasic pattern of release which suggests that the proposed receptors for glucose 


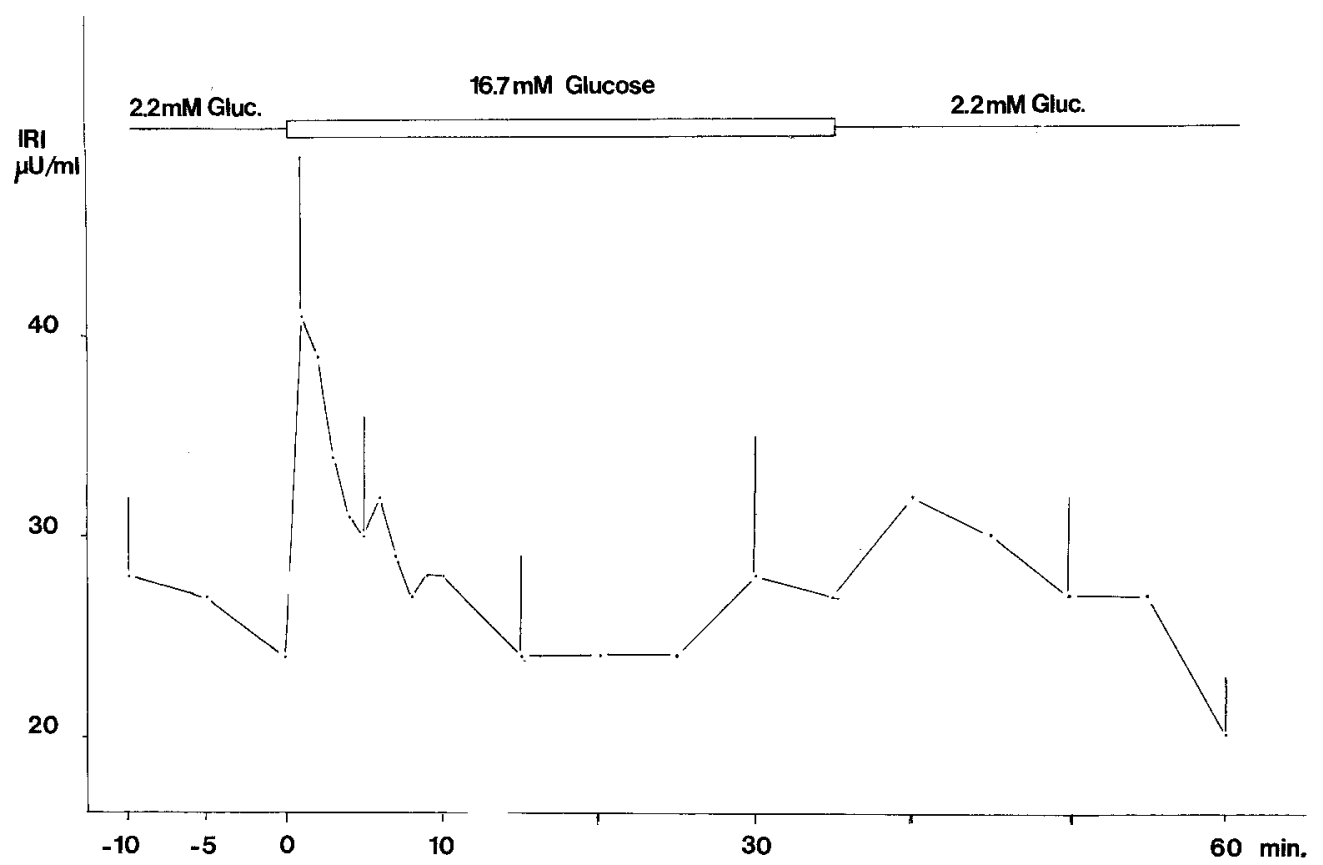

Fig. 3. The effect of glucose on the dynamics of insulin release from isolated islets of 21 day old fetal rats. The first three values represent the last $10 \mathrm{~min}$ of the $60 \mathrm{~min}$ prestimulation period with $2.2 \mathrm{mM}$ glucose, which is followed by the 35 min stimulation period with $16.7 \mathrm{mM}$ glucose. The experiments were terminated by the $25 \mathrm{~min}$ poststimulation period with $2.2 \mathrm{mM}$ glucose. Mean $\pm \mathrm{SEM} ; \mathrm{n}=15$

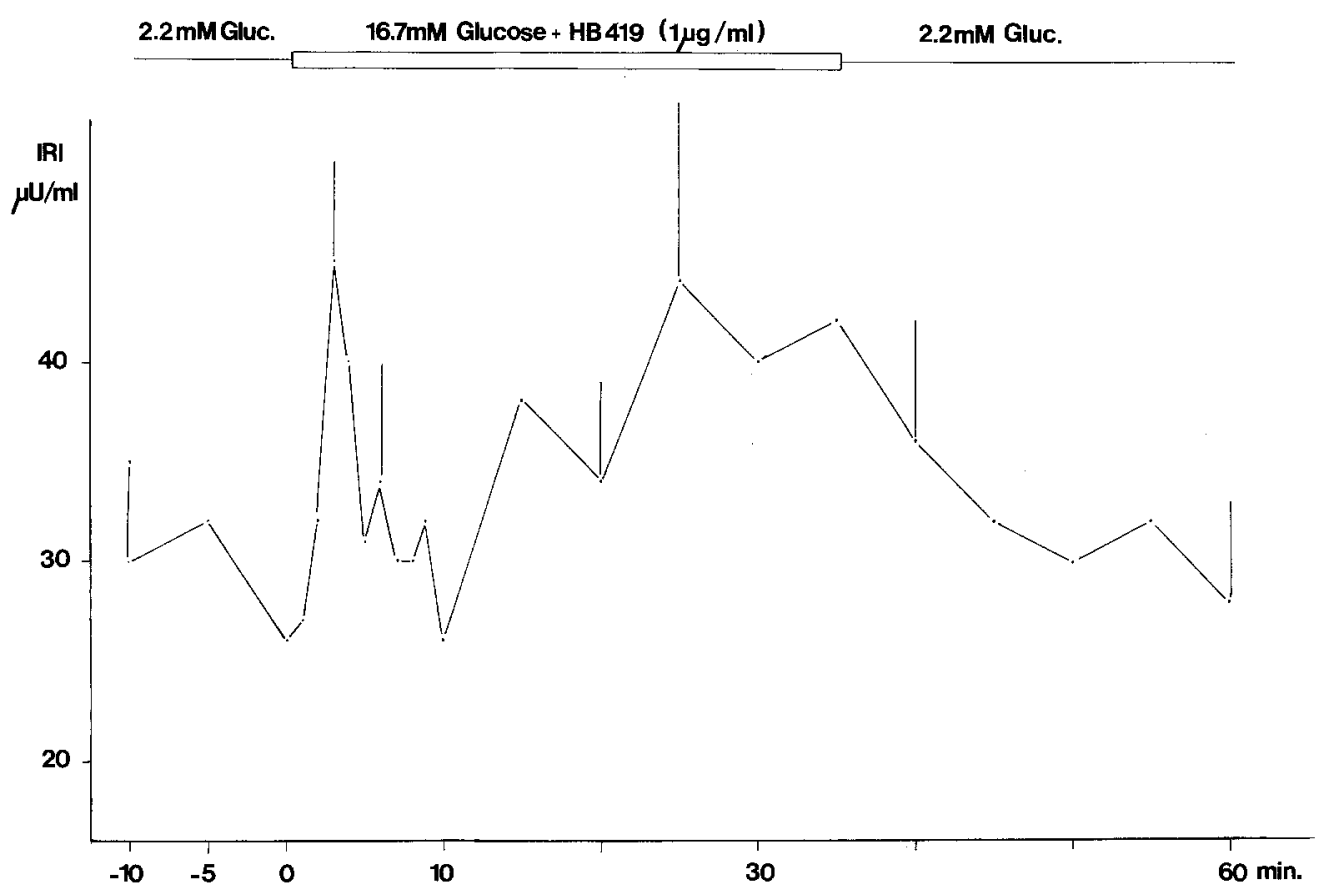

Fig. 4. The effect of glucose, $16.7 \mathrm{mM}$, plus glibenclamide (HB 419), $1 \mu \mathrm{g} / \mathrm{ml}$, on the dynamics of insulin release from isolated islets of 21 day old fetal rats. For experimental details see legend Fig. 3. Mean \pm SEM; $n=8$

and the sulfonylureas at the B-cell membrane may be differently altered by the collagenase treatment of the islets [24].

A comparison between the fetal and diabetic pattern of insulin release seems to be justified [1]. The fetal B-cell responds with a diminished insulin release to glucose stimulation, a situation which has been repeatedly found in mild diabetics, while the results reported for the prediabetic have been conflicting, partly depending on the definition of prediabetes $[6$, 


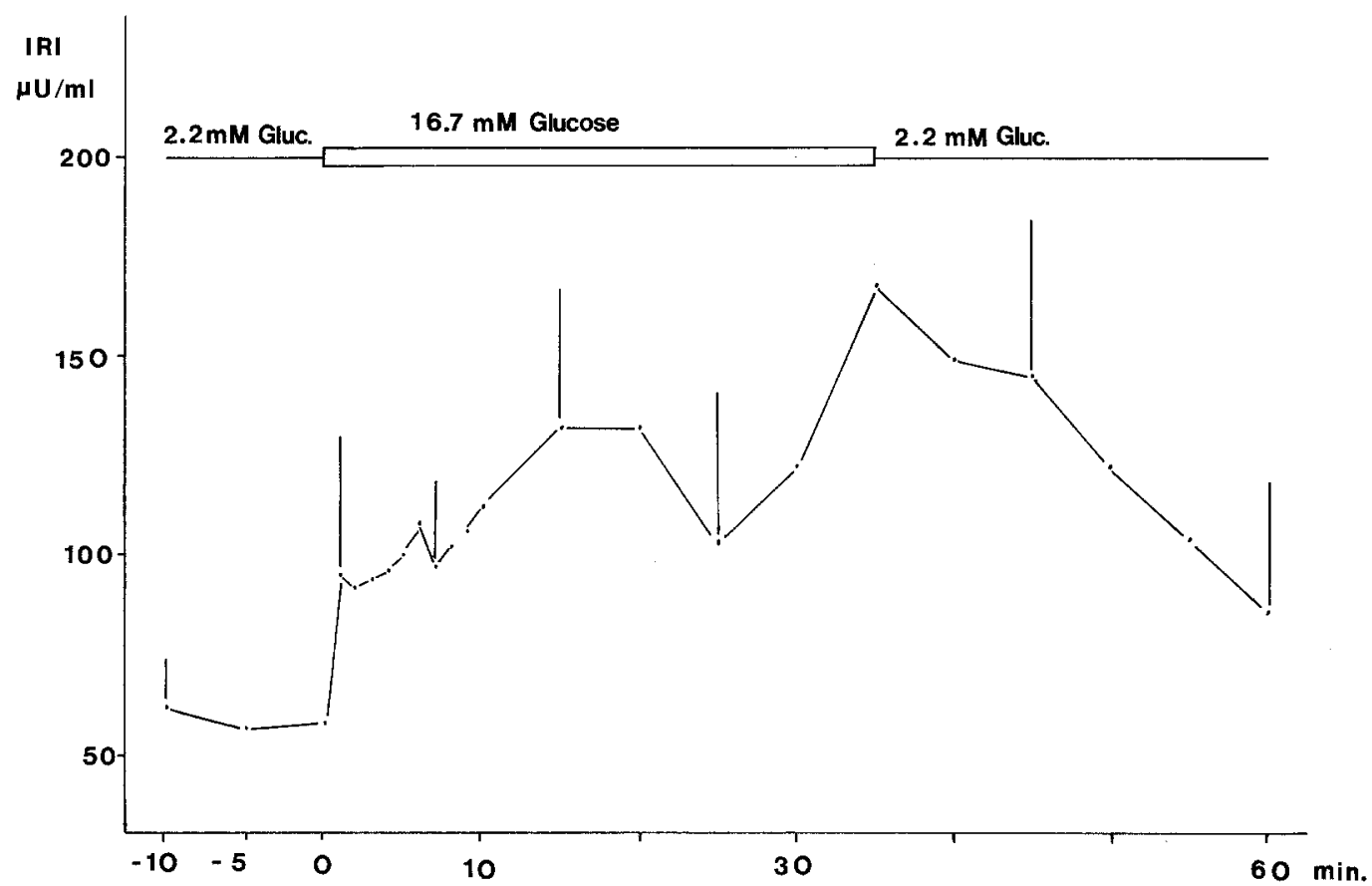

Fig. 5. The effect of glucose, $16.7 \mathrm{mM}$, on the dynamics of insulin release from isolated islets of 5 day old newborn rats. For experimental details see Fig. 3. Mean \pm SEM; $n=6$

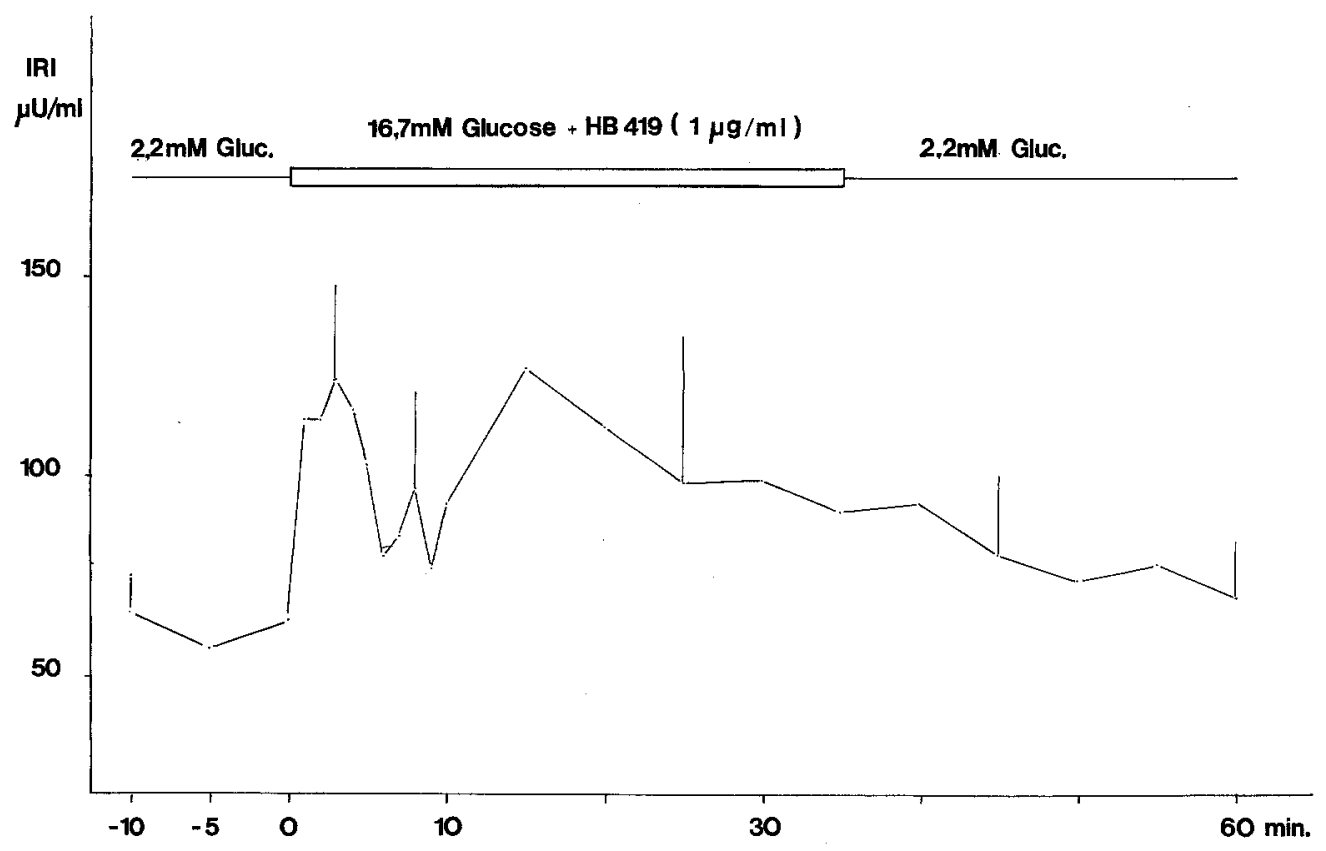

Fig. 6. The effect of glucose, $16.7 \mathrm{mM}$, plus glibenclamide ( $\mathrm{HB} 419), 1 \mu \mathrm{g} / \mathrm{ml}$, on the dynamics of insulin release from isolated islets of 5 day old newborn rats. For experimental details see Fig. 3. Mean \pm SEM; $n=8$

$7,25,26]$. A wider definition of prediabetics has been offered, separating those individuals from normals who showed a low initial and a delayed and decreased second phase of insulin secretion under a high constant glucose infusion [27]. In the more strict definition of genetically determined prediabetes, however, a normal or decreased insulin response to glucose has been found. But when the decrease of the blood sugar was correlated with the insulin released, it was found that the relative response was diminished $[6,7]$. On the other hand, with tolbutamide as the stimulus either no difference or a decreased insulin secretion 
Table 1. The effect of glucose and glucose plus glibenclamide (HB 419) on the dynamics of insulin release from isolated islets of 21 day old fetal and 5 day old newborn rats. The mean insulin release of the four different time intervals was calculated for each single experiment. The results are expressed as per cent, where the basal insulin secretion during the prestimulation period-from-10 to 0 minwas taken as one hundred per cent

Time $(\mathrm{min})$

\begin{tabular}{l|l|r|c|c|c|c}
\cline { 5 - 6 } \multicolumn{1}{c|}{ Age } & Substance & $\mathrm{n}$ & $-10-0$ & $1-6$ & $10-35$ & $35-60$ \\
\hline Fetal & Glucose & 15 & $100 \pm 12^{\mathrm{a}}$ & $146 \pm 15^{\mathrm{c}}$ & $103 \pm 14$ & $112 \pm 18$ \\
Newborn & Glucose & 6 & $100 \pm 17$ & $163 \pm 26^{\mathrm{b}}$ & $217 \pm 54^{\mathrm{b}}$ & $138 \pm 26$ \\
Fetal & Glucose + HB 419 & 8 & $100 \pm 13$ & $134 \pm 14^{\mathrm{b}}$ & $138 \pm 17^{\mathrm{b}}$ & $119 \pm 22$ \\
Newborn & Glucose + HB 419 & 8 & $100 \pm 12$ & $172 \pm 20^{\mathrm{c}}$ & $185 \pm 19^{\mathrm{b}}$ & $120 \pm 19$
\end{tabular}

$\mathrm{n}=$ number of individual islets preparations.

${ }^{\mathrm{a}}$ Mean \pm SEM $;{ }^{b} p<0.05 ;{ }^{\mathrm{c}}<0.01$;

significance of difference from the basal insulin secretion.

has been described between the prediabetic and the normal controls [5, 27].

The results reported in this study, that glibenclamide increases the secretion of insulin from the fetal islets, demonstrate another similarity between the prediabetic and the fetal pattern of insulin secretion, while in previous studies it was already shown that in both situations arginine $[11,28]$ and the methylxanthines [11, 29] improve the impaired glucose-induced insulin secretion to normal.

Acknowledgment. We are indebted to Mrs. Waltraud Schunk for her excellent technical assistence.

\section{Reference}

1. Williams, R.H., Ensinck, J.W.: Current studies regarding diabetes. Arch. intern. Med. 128, 820-831 (1971)

2. Burr, I.M., Kanazawa, Y., Marliss, E.B., Lambert, A.E.: Biphasic insulin release from perifused cultured fetal rat pancreas. Diabetes 20, 592-597 (1971)

3. Alexander, D.P., Britton, H.G., Cohen, N.M., Nixon, D.A., Parker, R. A.: Insulin secretion in the fetal and neonatal sheep. Biol. Neonat. (Basel) 22, 99-118 (1973)

4. Grasso, S., Messina, A., Saporito, M., Reitano, G.: Effect of theophylline, glucagon and theophylline plus glucagon on insulin secretion in the premature infant. Diabetes 19, 837-841 (1970)

5. Rojas, L., Soeldner, J.S., Gleason, R.E., Kahn, C.B., Marble, A.: Offspring of two diabetic parents: differential serum insulin responses to intravenous glucose and tolbutamide. J. clin. Endocr. 29, 1569-1579 (1969)

6. Colwell, J. A., Lein, A.: Diminished insulin response to hyperglycemia in prediabetes. Diabetes 16, 560-565 (1967)

7. Boden, G., Soeldner, J.S., Gleason, R.E., Marble, A.: Elevated serum insulin response to glucose in genetic prediabetic males with normal glucose tolerance. J. clin. Invest. 47, $729-739$ (1968)

8. Asplund, K., Westman, S., Hellerström, S.: Glucose stimulation of insulin secretion from the isolated pancreas of fetal and newborn rats. Diabetologia 5, 260-262 (1968)
9. Heinze, E., Steinke, J.: Glucose metabolism of isolated pancreatic islets: difference between fetal, newborn and adult rats. Endocrinology 88, 1259-1263 (1971)

10. Sodoyez-Goffaux, F., Sodoyez, J., Foa, P.P.: Effects of gestational age, birth and feeding on the insulinogenic response to glucose and tolbutamide by fetal and newborn rat pancreas. Diabetes 20, 586-591 (1971)

11. Heinze, E., Steinke, J.: Insulin secretion during development: response of isolated pancreatic islets of fetal, newborn and adult rat to theophylline and arginine. Horm. Metab. Res. 4, 234 236 (1972)

12. Lacy, P.E., Kostianovsky, Y.M.: Method for the isolation of intact islets of Langerhans. Diabetes 16, 35-39 (1967)

13. Stork, H., Schmidt, F.H.: Mitteilung über eine enzymatische Schnellmethode zur Bestimmung des Blutzuckers in $5 \mu \mathrm{l}$ Capillarblut ohne Enteiweißung und ohne Zentrifugation. Klin. Wschr. 46, 789-790 (1968)

14. Melani, F., Ditschuneit, H., Bartelt, K.M., Friedrick, H., Pfeiffer, E.F.: Über die radioimmunologische Bestimmung von Insulin im Blut. Klin. Wschr. 143, 1000-1007 (1965)

15. Steinke, J., Patel, T.N., Ammon, H.P.T.: Relationship between glucose and tolbutamide induced insulin release and insulin content in single pancreatic rat islets. Metabolism 21, $465-470(1972)$

16. Pfeiffer, E. F., Fußgänger, R., Hinz, M., Raptis, S.: Dynamics of insulin secretion: comparison of various in vitro preparations. In: The structure and metabolism of the pancreatic islets (eds. S. Falkmer, B. Hellman, I.B. Täljedal), Wenner-Gren Symposium 16, 423-433 (1969). Oxford and New York: Pergamon Press 1970

18. Clark, C.M., Cahill, G. F., Soeldner, J.S.: Effects of exogenous insulin on the rate of fatty acid synthesis and glucose C-14 utilization in the twenty-day rat fetus. Diabetes 17, 362-368 (1968)

19. Espinosa de los Monteros Mena, A., Steinke, J.: Isolated pancreatic islets: comparison of insulin release from fetuses and newborns of normal and alloxan diabetic rats. Diabetes $\mathbf{1 9}, 364$ (1970)

20. Girard, J.R., Kervran, A., Soufflet, E., Assan, R.: Factors affecting the secretion of insulin and glucagon by the rat fetus. Diabetes 23, 310-317 (1974)

21. Dunbar, J.C., Foa, P.P.: An inhibitory effect of tolbutamide and glibenclamide (Glyburide) on the pancreatic islets of normal animals. Diabetologia 10, $27-35$ (1974)

22. Idahl, L. A.: Dynamics of pancreatic $\beta$-cell responses to glucose. Diabetologia 9, 403-412 (1973) 
23. Lernmark, A.: Isolated mouse islets as a model for studying insulin release. Acta diabet. lat. 8, 649-79 (1971)

24. Hellmann, B., Sehlin, J., Täljedal, I.B.: The pancreatic $\beta$-cell recognition of insulin secretagogues. Diabetologia 9, 210-216 (1973)

25. Seltzer, H.S., Allen, E.W., Herron, A.L., Brennan, M.T., Jr.: Insulin secretion in response to glycemic stimulus: reaction of delayed insulin in carbohydrate intolerance in mild diabetes mellitus. J. clin. Invest. 46, 323-335 (1967)

26. Cerasi, E., Luft, R.: Insulin response to glucose infusion in diabetic and non-diabetic monozygotic twin pairs. Genetic control of insulin response? Acta Endocr. 55, 330-345 (1967)

27. Cerasi, E., Luft, R.: Further studies on healthy subjects with low and high insulin response to glucose infusion. Acta Endocr. 55, $305-329$ (1967)
28. Efendic, S., Cerasi, E., Luft, R.: Quantitative study on the potentiating effect of arginine on glucose induced insulin response in healthy, prediabetic and diabetic subjects. Diabetes 23, 161-171 (1974)

29. Cerasi, E., Luft, R.: The effect of an adenosine-3',5'-monophosphate diesterase inhibitor (aminophylline) on insulin response to glucose infusion in prediabetic and diabetic subjects. Horm. Metab. Res. 1, 162-168 (1969)

Dr. med. E. Heinze

Univ. Ulm

Zentrum der Inneren Medizin

$79 \mathrm{Ulm} /$ Donau

Prittwitzstr. 43 